\title{
Scientific and Industrial Research in New Zealand
}

$\mathrm{T}$ HE twelfth annual report of the Department of Scientific and Industrial Research, New Zealand, includes the Minister's statement, together with the Secretary's report, and the reports of the various research committees, institutes or bureaux under the Council. Some account of research work at Canterbury Agricultural College is included, and also of the work of the Geological Survey Branch, the Meteorological Branch, the Dominion Observatory and the Apia and Magnetic Observatories. Referring to the work of the Meteorological Branch, the Minister emphasizes its growing importance as a result of the rapid expansion of commercial aviation within New Zealand and the development of trans-oceanic aircraft. The Geological Survey Branch has gained importance through the Government's proposals in regard to the establishment of an iron and steel industry, and also through the recent activity of oil prospecting, with its emphasis on the importance of accurate data on geological structure and mineral resources of the Dominion. During the year, the Soils Survey Division of the Department has carried out an extensive programme of work in Hawke's Bay, North Auckland, Blenheim, West Coast and Bank's Peninsula, the results of which are being published. The Soils Survey Division has also contributed important data collected in the course of soil surveys which bear on the problem of soil erosion and land deterioration in New Zealand.

These activities fall under the broad section of the activities of the Department which is concerned with provision of essential scientific services to the Government. In this section is also included the work of the Dominion Laboratory, which has recently carried out much work for the Housing Department in connexion with the examination of a wide range of building materials, and has given valuable advice as to the durability and general standard of the materials used. The laboratory is also carrying out important industrial research work, particularly in relation to the phormium, kauri gum and fruit industries, and has almost completed an investigation of the curing of lemons, which has given results of real value to the industry. The work of the Plant Research
Bureau has been further consolidated and is now a major branch of the Department's activity. The Botany Section (now established in Wellington) has been engaged in two major investigations which have a bearing on economic problems-ragwort and South Island tussock grasslands. These studies have revealed the remarkable capacity of the ragwort to regenerate from root fragments, and have indicated that toxic sprays seldom injure the plant to such an extent that regeneration of roots will not occur. The Entomological Division has largely centred on measures designed to control the two principal insect pests of rape and turnip crops and has undertaken a study of insect pests of wheat. Work has also been completed on the effect of Agrosan and Ceresan dusts on the seed of wheat, oats, barley and peas, and has shown that little or no adverse effects can be detected on the treated seeds when stored for periods less than five months, either in subsequent germination or in the control of disease. The Plant Diseases Division has made good progress with spray testing technique, and with the growing of pyrethrum. Attention has also been devoted to problems of industrial mycology.

The Dairy Research Institute has been responsible for important advances in the study of the technique for the maintenance of single strain starters, and in this connexion the experience of the Institute has emphasized the importance of the technical education of managing foremen in industrial efficiency. Now research associations have been established to provide a co-ordinated scientific and technical service for the woollen manufacturing, boot and shoe manufacturing and tobacco industries. The newly-formed Social Science Research Bureau has directed its activities to a study of the standard of living of dairy farmers. The study of dietary requirements has been handed over to the Medical Research Council, at a stage where family diets have been formulated giving sufficient energy and protective food values. The report also includes accounts of the work of the Wheat Research Institute, of the Fruit Research and Radio Research, as well as of the work of the Standards Institute.

\section{Protection of the Natives of Dutch New Guinea}

$\mathrm{M}^{\mathrm{H}}$ $\mathrm{EN}$ of science in Holland have been by no means blind to the havoc which is being caused, especially among fauna and flora, by Western exploitation of natural resources in the remoter parts of the world. They also appreciate to the full the deleterious effects of the impact of Western civilization on primitive peoples. This latter problem is one which has been brought home to them with peculiar force and urgency, not only on behalf of the native populations under Dutch administration in Indonesia, but also owing to the prospective rapid development of the natural resources of Dutch New Guinea in the near future, where the use of aeroplanes by the great oil interests and also prospecting for minerals are bringing about the speedy opening up of the hitherto inaccessible interior.

On April 29, 1937, the Netherlands Committee for International Nature Protection, an influential body which came into being, as its name implies, for promoting international co-operation in devising measures for preventing or alleviating the grosser and more harmful results in Nature of the spread of civilization 
appointed a sub-committee to consider measures for the protection of the natives of Dutch New Guinea. This sub-committee was composed of members eminent in science, or with experience of primitive peoples and of industrial organization in the tropics. Among them were Prof. O. de Vries, of the Government Agricultural Experimental Station at Groningen, Dr. A. J. M. van W. van der Gracht, of the Government Service for the Supervision of Mines, and Dr. H. J. T. Bijlmer, whose expedition to the mountain region of Dutch New Guinea in 1936 effected contacts with native peoples who had never previously seen a white man. The sub-committee has prepared a report, which has been adopted by the main committee and has recently been submitted for consideration to the Governor-General of the Dutch Indies and the Minister for the Colonies*.

The native problem, it is pointed out by the Committee in its report, is twofold. The population of the coastal lands, which on broad lines is already known geographically, consists of tribes of Papuan stock, which already have been in contact with Europeans, official, mission and other, for some decades. These tribes are fierce and warlike, cannibals and headhunters, among whom murder and manslaughter are rife. Some of them are still uninfluenced by civilization. In the mountain region, until recently almost entirely unexplored, on the other hand, the inhabitants are Papuans of a specialized type, some indeed of so low a stature as almost to warrant the designation of pygmies. Of these a few only had been reached in recent years by scientific expeditions, and that with extreme difficulty, before the aeroplane made the country more readily accessible. The culture of these mountain peoples is of a different order from that of the peoples of the coastal lands. They cultivate gardens and keep pigs, are industrious, and have settled habitations, while their warfare is of a mild type. In disposition they are friendly, and greet European contacts in an amicable spirit.

Two alternative methods of dealing with the native problem presented themselves to the Committee for consideration. Of these the first was the complete segregation of the native population from all contacts with civilization in a native reserve, in which they might be preserved with their culture as museum specimens. The second alternative was the protection of the native population from the effects of a full and sudden impact of white civilization-the abruptness of the impact constituting, it was felt, the essential danger-by a process of gradual preparation and education, in which contact with European influence would be subject to stringent and careful regulation.

The Committee elected in favour of the latter course as the more practical, and at the same time the more fair to the native, as it would leave open to him the possibility of cultural development, from which, it was felt, he should not be debarred, as he would be under the first alternative.

It is, therefore, suggested that provision should be made for three stages of development and contact : (1) a period of gradual reconnoitring and penetration, research and study, with a minimum of native control by Government agencies ; (2) a period of gradual building up of a new culture. the introduction of

- Netherlands Committee for International Nature Protection: Report concerning the Possibility of Protecting the Primitive Natives, especially the Mountain-Papuan-Tribes in Dutch New Guinea. Pp. 32. (Amsterdam: Nederlandsche Commissie voor Internationale Natuurbescherming.) missions and mission schools, the intensification of Government functions, with a recognition of native authorities, and the extension of communications, and other forms of economic development; and (3) the normal colonial condition of Dutch administration, with co-operation with, and recognition of, local native autonomy.

In order to bring about the smooth development of these three stages of progress, certain regulations are suggested, which include the declaration of population reserves, in which in addition to the existing regulations as to permits for entrance, no Eastern immigrants should be admitted, and no corporate or individual enterprise should be allowed except under special conditions framed to protect the interests of the natives. As a condition of admission to New Guinea, medical examination and precaution against infectious or other disease should be added to the requirement of a permit; the importation of all alcohol and drugs should be prohibited; and the importation and sale of drapery goods should also be prohibited in order to enforce the wearing of the native type of clothing. Further, the establishment of estates should be subject to regulation, ensuring the preservation of sufficient agricultural land for the needs of the native population, while the importation of labour and recruiting of indigenous labour should be regulated. A large area of the mountain region should be declared a reserve, though not debarred to prospecting, which being for the most part of a transient character should not, under permit, affect the interests of the native population. This large reserve, when known ethnologically, and technically explored, might be broken up into smaller units.

It will be seen that the Committee, in framing its recommendations, has wisely aimed at reconciling the efficient protection of the interests of the indigenous population with the opening up and commercial development of this valuable territory. In framing its policy it has been, as is duly acknowledged, much indebted to the measures taken by the Australian Government for the administration of the Mandated Territory of New Guinea, and above all to the conceptions in native administration of Governor General Sir Hubert Murray.

\section{University Events}

BeLFAST.-The title of professor emeritus has been conferred on Prof. F. Hummel, who retired recently from the chair of civil engineering.

Edinburgh.-On January 11, Sir William Bragg formally opened the new common room of the University, situated at King's Buildings, West Mains Road. It is designed to meet the physical and social needs of the students of science, most of whose work is done at King's Buildings. During the ceremony, it was announced that Dr. J. A. Thomson had given $£ 5,000$ and promised up to $£ 10,000$ towards the maintenance of the building.

Sir William Bragg also took the chair at the inaugural lecture of the newly instituted lectureship of crystallography. The lectureship was founded by a fund left by Lady Dewar, widow of Sir James Dewar, in 1936, and the lecture was delivered by Dr. C. A. Beevers, Dewar research fellow. 